\title{
Evaluation of Target Volume Determination for Irradiation of Pilocytic Astrocytomas: An Original Article
}

\author{
Omer Sager*, Ferrat Dincoglan, Selcuk Demiral, Murat Beyzadeoglu \\ Department of Radiation Oncology, University of Health Sciences, Gulhane Medical Faculty, Ankara, Turkey \\ *Corresponding Author: Omer Sager, Department of Radiation Oncology, University of Health \\ Sciences, Gulhane Medical Faculty, Ankara, Turkey
}

\begin{abstract}
Background: Pilocytic astrocytomas are the most frequent gliomas in children. Radiation therapy (RT) may have a role in management of pilocytic astrocytomas either as an adjunctive, salvage or primary treatment in selected patients. Nevertheless, toxicity profile of considered treatments are an important concern for management of pilocytic astrocytomas. Determination of target volumes for irradiation of pilocytic astrocytomas constitutes a critical part of radiotherapeutic management and has been poorly addressed in the literature. In this context, we evaluate incorporation of multimodality imaging with magnetic resonance imaging (MRI) into target volume determination for irradiation of pilocytic astrocytomas in this original research article.
\end{abstract}

Materials and Methods: RT treatment volume determination based on multimodality imaging with incorporation of MRI or by use of computed tomography (CT)-simulation images only has been comparatively assessed for patients with pilocytic astrocytoma in our study.

Results and Conclusion: Radiation treatment planning has been performed by the available treatment planning system at our department. Optimal target coverage with minimization of normal tissue exposure has been prioritized. Synergy (Elekta, UK) LINAC has been utilized for treatment delivery. Irradiation treatment volume definition by CT-only imaging and by CT-MR fusion based imaging was comparatively evaluated in this study. Ground truth target volume determined by the board-certified radiation oncologists after thorough assessment, collaboration, colleague peer review and ultimate consensus has been found to be identical to target definition by use of CT-MR fusion based imaging. In conclusion, treatment volume definition constitutes a critical part of irradiation for pilocytic astrocytomas. Incorporation of MRI into the treatment volume determination procedure for improved radiation treatment planning for pilocytic astrocytomas may be considered to achieve optimal outcomes despite the need for further supporting evidence.

Keywords: Pilocytic Astrocytoma, Irradiation, Magnetic Resonance Imaging (MRI)

\section{INTRODUCTION}

Pilocytic astrocytomas are the most frequent gliomas in children. Radiation therapy (RT) may have a role in management of pilocytic astrocytomas either as an adjunctive, salvage or primary treatment in selected patients. Nevertheless, toxicity profile of considered treatments are an important concern for management of pilocytic astrocytomas. Since children comprise a considerable proportion of the patients, long term adverse effects should be taken into account in decision making for treatment. Pilocytic astrocytomas typically follow an excellent prognosis which renders quality of life an endpoint of utmost importance. Depending on the location of lesion and its association with critical surrounding structures, a variety of adverse effects may occur due to irradiation. In this context, omission or deferral of RT may be considered on an individualized basis for patients with pilocytic astrocytoma. Nevertheless, irradiation in the forms of conventionally fractionated RT (CFRT) or radiosurgery as Stereotactic Radiosurgery (SRS), Hypofractionated Stereotactic Radiotherapy (HFSRT), and Stereotactic Body Radiotherapy (SBRT) may be judiciously used for optimal management of several central nervous system (CNS) disorders as well as a variety of other tumors throughout the human body with promising results [1, 38]. Determination of target volumes for irradiation 
of pilocytic astrocytomas constitutes a critical part of radiotherapeutic management and has been poorly addressed in the literature. In this context, we evaluate incorporation of multimodality imaging with magnetic resonance imaging (MRI) into target volume determination for irradiation of pilocytic astrocytomas in this original research article.

\section{MATERIALS AND METHODS}

RT treatment volume determination based on multimodality imaging with incorporation of MRI or by use of computed tomography (CT)simulation images only has been comparatively assessed for patients with pilocytic astrocytoma in our study. Ground truth target volume to be used as the reference for actual treatment and comparison purposes was determined by the board-certified radiation oncologists after thorough evaluation, colleague peer review, collaboration, and ultimate consensus. Comprehensive assessment was performed considering the lesion size, location, patient symptomatology and preferences along with expected outcomes of treatment individually. Treatment simulation for RT planning has been performed at the CT-simulator (GE Lightspeed RT, GE Healthcare, Chalfont St. Giles, UK) available in our institution. Planning CT images were acquires and then sent to the contouring workstation (SimMD, GE, UK) for delineation of treatment volumes and organs at risk. Either CT-simulation images only or fused CT and MR images have been used for treatment volume determination for irradiation. Treatment volume definition with CT only and by incorporation of CT-MR fusion has been comparatively assessed. Determination of ground truth target volume has been performed by the board-certified radiation oncologists after thorough evaluation, collaboration, colleague peer review and ultimate consensus to be used for actual treatment as well as for comparison purposes. Treatment delivery has ben performed by Synergy (Elekta, UK) linear accelerator (LINAC) available at our tertiary cancer center.

\section{RESULTS}

Radiation treatment planning has been performed by the available treatment planning system at our department. Optimal target coverage with minimization of normal tissue exposure has been prioritized. Synergy (Elekta, UK) LINAC has been utilized for treatment delivery. Irradiation treatment volume definition by CT-only imaging and by CT-MR fusion based imaging was comparatively evaluated in this study. Ground truth target volume determined by the board-certified radiation oncologists after thorough assessment, collaboration, colleague peer review and ultimate consensus has been found to be identical to target definition by use of CT-MR fusion based imaging.

\section{DISCUSSION}

Pilocytic astrocytomas comprise the most common gliomas in children. These tumors are typically low grade tumors following an indolent disease course. Irradiation can be used for management of pilocytic astrocytomas as an adjunct therapy or in the setting of recurrences. There has been considerable growth in irradiation capacity of several cancer centers for a plethora of benign and malign conditions. Also, important advances have been introduced in the discipline of radiation oncology including adaptive irradiation strategies and state of the art treatment delivery techniques such as incorporation of molecular imaging, automatic segmentation procedures, Image Guided Radiation Therapy (IGRT), Adaptive Radiation Therapy (ART), Intensity Modulated Radiation Therapy (IMRT), Breathing Adapted Radiation Therapy (BART), and stereotactic irradiation with SRS, HFSRT, and SBRT [38, 49].

Determination of irradiation target volumes constitutes a critical part of radiotherapeutic management of pilocytic astrocytomas. Avoiding geopraphical misses and untowards radiation induced toxicity are pertinent goals of irradiation in the millennium era. Determination of larger target volumes may lead to severe toxicity associated with RT, nevertheless, definition of smaller than actual target volumes may result in geopraphical misses and subsequent disease progression. Addition of multimodality imaging may be utilized for improving the accuracy of treatment volume localization, and combined use of fused CT and MR images may aid in optimizing target volume definition for RT. There is scant data in the literature addressing the utility of multimodality imaging for radiation treatment planning of pilocytic astrocytomas. In this context, this study may add to the existing literature.

\section{CONCLUSiON}

In conclusion, treatment volume definition constitutes a critical part of irradiation for pilocytic astrocytomas. Incorporation of MRI 
into the treatment volume determination procedure for improved radiation treatment planning for pilocytic astrocytomas may be considered to achieve optimal outcomes despite the need for further supporting evidence.

\section{REFERENCES}

[1] Beyzadeoglu, M., Dincoglan, F., Sager, O., Demiral, S. (2020) Determination of Radiosurgery Treatment Volume for Intracranial Germ Cell Tumors (GCTS). Asian Journal of Pharmacy, Nursing and Medical Sciences, 8(3): 18-23. https://doi.org/10.24203 /ajpnms.v8i3.6120

[2] Beyzadeoglu M, Sager O, Dincoglan F, Demiral S, Uysal B, et al. (2020) Single Fraction Stereotactic Radiosurgery (SRS) versus Fractionated Stereotactic Radiotherapy (FSRT) for Vestibular Schwannoma (VS). J Surg Surgical Res 6(1): 062-066.DOI: https://dx.doi.org/10.17352/2455-2968.000099

[3] Sager O, Beyzadeoglu M, Dincoglan F, Demiral S, Gamsiz H, et al. (2020) Multimodality management of cavernous sinus meningiomas with less extensive surgery followed by subsequent irradiation: Implications for an improved toxicity profile. J Surg Surgical Res 6(1): 056-061. DOI: https://dx.doi.org/10.17352/2455-2968.000098

[4] Sager O, Dincoglan F, Demiral S, Beyzadeoglu M (2020) Radiosurgery Treatment Volume Determination for Brain Lymphomas with and without Incorporation of Multimodality Imaging. Journal of Medical Pharmaceutical and Allied Sciences 9: 23982404.

[5] Dincoglan F, Beyzadeoglu M, Sager O, Demiral S, Uysal B, et al. (2020) A Concise Review of Irradiation for Temporal Bone Chemodectomas (TBC). Arch Otolaryngol Rhinol 6: 016-020.

[6] Sager O, Demiral S, Dincoglan F, Beyzadeoglu M (2020) Target Volume Definition for Stereotactic Radiosurgery (SRS) Of Cerebral Cavernous Malformations (CCMs). Canc Therapy \& Oncol Int J 15: 555917.

[7] Dincoglan F, Demiral S, Sager O, Beyzadeoglu M (2020) Utility of Multimodality Imaging Based Target Volume Definition for Radiosurgery of Trigeminal Neuralgia: An Original Article. Biomed J Sci \& Tech Res 26: 19728-19732.

[8] Demiral S, Beyzadeoglu M, Sager O, Dincoglan F, Gamsiz H, et al. (2014) Evaluation of Linear Accelerator (Linac)Based Stereotactic Radiosurgery (Srs) for the Treatment of Craniopharyngiomas. UHODUluslararasi Hematoloji Onkoloji Dergisi 24(2): 123-129.
[9] Demiral S, Beyzadeoglu M, Dincoglan F, Sager O (2020) Assessment of Target Volume Definition for Radiosurgery of Atypical Meningiomas with Multimodality Imaging. Journal of Hematology and Oncology Research 3: 14-21.

[10] Sager O, Dincoglan F, Demiral S, Gamsiz H, Uysal B, et al. (2019) Utility of Magnetic Resonance Imaging (Imaging) in Target Volume Definition for Radiosurgery of Acoustic Neuromas. Int J Cancer Clin Res 6: 119.

[11] Dincoglan F, Sager O, Uysal B, Demiral S, Gamsiz H, et al. (2019) Evaluation of hypofractionated stereotactic radiotherapy (HFSRT) to the resection cavity after surgical resection of brain metastases: A single center experience. Indian J Cancer 56: 202-206.

[12] Dincoglan F, Sager O, Demiral S, Gamsiz H, Uysal B, et al. (2019) Fractionated stereotactic radiosurgery for locally recurrent brain metastases after failed stereotactic radiosurgery. Indian J Cancer 56: 151-156.

[13] Dincoglan F, Sager O, Demiral S, Beyzadeoglu M (2019) Incorporation of Multimodality Imaging in Radiosurgery Planning for Craniopharyngiomas: An Original Article. SAJ Cancer Sci 6: 103.

[14] Beyzadeoglu M, Sager O, Dincoglan F, Demiral S (2019) Evaluation of Target Definition for Stereotactic Reirradiation of Recurrent Glioblastoma. Arch Can Res 7: 3.

[15] Sager O, Dincoglan F, Demiral S, Beyzadeoglu M (2019) Evaluation of Radiosurgery Target Volume Determination for Meningiomas Based on Computed Tomography (CT) And Magnetic Resonance Imaging (MRI). Cancer Sci Res Open Access 5: $1-4$.

[16] Demiral S, Sager O, Dincoglan F, Beyzadeoglu M (2019) Assessment of Computed Tomography (CT) And Magnetic Resonance Imaging (MRI) Based Radiosurgery Treatment Planning for Pituitary Adenomas. Canc Therapy \& Oncol Int J 13: 555857.

[17] Dincoglan F, Sager O, Demiral S, Beyzadeoglu M (2019) Multimodality Imaging for Radiosurgical Management of Arteriovenous Malformations. Asian Journal of Pharmacy, Nursing and Medical Sciences 7: 7-12.

[18] Demiral S, Sager O, Dincoglan F, Beyzadeoglu M (2019) Assessment of target definition based on Multimodality imaging for radiosurgical Management of glomus jugulare tumors (GJTs). Canc Therapy \& Oncol Int J 15: 555909.

[19] Sager O, Dincoglan F, Demiral S, Gamsiz H, Uysal B, et al. (2019) Evaluation of the Impact 
of Magnetic Resonance Imaging (MRI) on Gross Tumor Volume (GTV) Definition for Radiation Treatment Planning (RTP) of Inoperable High Grade Gliomas (HGGs). Concepts in Magnetic Resonance Part A 2019, Article ID 4282754.

[20] Demiral S, Sager O, Dincoglan F, Uysal B, Gamsiz H, et al. (2018) Evaluation of Target Volume Determination for Single Session Stereotactic Radiosurgery (SRS) of Brain Metastases. Canc Therapy \& Oncol Int J 12: 555848.

[21] Demiral S, Dincoglan F, Sager O, Uysal B, Gamsiz H, et al. (2018) Contemporary Management of Meningiomas with Radiosurgery. Int J Radiol Imaging Technol 80: $187-190$.

[22] Dincoglan F, Sager O, Demiral S, Uysal B, Gamsiz H, et al. (2017) Radiosurgery for recurrent glioblastoma: A review article. Neurol Disord Therap 1: 1-5.

[23] Demiral S, Dincoglan F, Sager O, Gamsiz H, Uysal B, et al. (2016) Hypofractionated stereotactic radiotherapy (HFSRT) for who grade I anterior clinoid meningiomas (ACM). Jpn J Radiol 34: 730-737.

[24] Gamsiz H, Beyzadeoglu M, Sager O, Demiral S, Dincoglan F, et al. (2015) Evaluation of stereotactic body radiation therapy in the management of adrenal metastases from nonsmall cell lung cancer. Tumori 101: 98-103.

[25] Dincoglan F, Beyzadeoglu M, Sager O, Demiral S, Gamsiz H, et al. (2015) Management of patients with recurrent glioblastoma using hypofractionated stereotactic radiotherapy. Tumori 101: 179-184.

[26] Sager O, Dincoglan F, Beyzadeoglu M (2015) Stereotactic radiosurgery of glomus jugulare tumors: Current concepts, recent advances and future perspectives. CNS Oncol 4: 105-114.

[27] Gamsiz H, Beyzadeoglu M, Sager O, Dincoglan F, Demiral S, et al. (2014) Management of pulmonary oligometastases by stereotactic body radiotherapy. Tumori 100: 179-183.

[28] Dincoglan F, Sager O, Gamsiz H, Uysal B, Demiral S, et al. (2014) Management of patients with $\geq 4$ brain metastases using stereotactic radiosurgery boost after whole brain irradiation. Tumori 100: 302-306.

[29] Demiral S, Beyzadeoglu M, Sager O, Dincoglan F, Gamsiz H, et al. (2014) Evaluation of linear accelerator (linac)-based stereotactic radiosurgery (srs) for the treatment of craniopharyngiomas. UHOD - Uluslararasi Hematoloji-Onkoloji Dergisi 24: 123-129.

[30] Sager O, Beyzadeoglu M, Dincoglan F, Uysal B, Gamsiz H, et al. (2014) Evaluation of linear accelerator (LINAC)-based stereotactic radiosurgery (SRS) for cerebral cavernous malformations: A 15-year single-center experience. Ann Saudi Med 34: 54-58.

[31] Sager O, Beyzadeoglu M, Dincoglan F, Gamsiz H, Demiral S, et al. (2014) Evaluation of linear accelerator-based stereotactic radiosurgery in the management of glomus jugulare tumors. Tumori 100: 184-188.

[32] Dincoglan F, Beyzadeoglu M, Sager O, Uysal B, Demiral S, et al. (2013) Evaluation of linear accelerator-based stereotactic radiosurgery in the management of meningiomas: A single center experience. J BUON 18: 717-722.

[33] Sager O, Beyzadeoglu M, Dincoglan F, Demiral S, Uysal B, et al. (2013) Management of vestibular schwannomas with linear accelerator-based stereotactic radiosurgery: a single center experience. Tumori 99: 617-622.

[34] Demiral S, Beyzadeoglu M, Uysal B, Oysul K, Kahya YE, et al. (2013) Evaluation of stereotactic body radiotherapy (SBRT) boost in the management of endometrial cancer. Neoplasma 60: 322-327.

[35] Dincoglan F, Beyzadeoglu M, Sager O, Oysul K, Sirin S et al. (2012) Image-guided positioning in intracranial non-invasive stereotactic radiosurgery for the treatment of brain metastasis. Tumori 98: 630-635.

[36] Dincoglan F, Sager O, Gamsiz H, Uysal B, Demiral S, et al. (2012) Stereotactic radiosurgery for intracranial tumors: A single center experience. Gulhane Med J 54: 190-1 98.

[37] Sirin S, Oysul K, Surenkok S, Sager O, Dincoglan F, et al. (2011) Linear acceleratorbased stereotactic radiosurgery in recurrent glioblastoma: A single center experience. Vojnosanit Pregl 68: 961-966.

[38] Dincoglan F, Beyzadeoglu M, Demiral S, Sager O (2020) Assessment of Treatment Volume Definition for Irradiation of Spinal Ependymomas: an Original Article. ARC Journal of Cancer Science Volume 6, Issue 1, 2020, PP 1-6 DOI: http://dx.doi.org/10. 20 431/2455-6009.0601001

[39] Sager O, Dincoglan F, Demiral S, Uysal B, Gamsiz H, et al. (2020) Adaptive radiation therapy of breast cancer by repeated imaging during irradiation. World J Radiol 12(5): 6875. doi: 10.4329/wjr.v12.i5.68

[40] Sager O, Dincoglan F, Demiral S, Uysal B, Gamsiz H, et al. (2019) Utility of Molecular Imaging with 2-Deoxy-2-[Fluorine-18] Fluoro-DGlucose Positron Emission Tomography (18F-FDG PET) for Small Cell Lung Cancer (SCLC): A Radiation Oncology Perspective. Curr Radiopharm 12: 4-10. 
[41] Sager O, Dincoglan F, Demiral S, Uysal B, Gamsiz H, et al. (2019) Breathing adapted radiation therapy for leukemia relapse in the breast: A case report. World J Clin Oncol 10: 369-374.

[42] Sager O, Dincoglan F, Uysal B, Demiral S, Gamsiz H, et al. (2018) Evaluation of adaptive radiotherapy (ART) by use of replanning the tumor bed boost with repeated computed tomography (CT) simulation after whole breast irradiation (WBI) for breast cancer patients having clinically evident seroma. Jpn J Radiol 36: 401-406.

[43] Sager O, Dincoglan F, Uysal B, Demiral S, Gamsiz H, et al. (2017) Splenic Irradiation: A Concise Review of the Literature. J App Hem Bl Tran 1: 101.

[44] Sager O, Beyzadeoglu M, Dincoglan F, Demiral S, Uysal B, et al. (2015) Adaptive splenic radiotherapy for symptomatic splenomegaly management in myeloproliferative disorders. Tumori 101: 84-90.

[45] Özsavaş EE, Telatar Z, Dirican B, Sağer Ö, Beyzadeoğlu M (2014) Automatic segmentation of anatomical structures from CT scans of thorax for RTP. Comput Math Methods Med 2014: 472890.
[46] Dincoglan F, Beyzadeoglu M, Sager O, Oysul K, Kahya YE, et al. (2013) Dosimetric evaluation of critical organs at risk in mastectomized left-sided breast cancer radiotherapy using breath-hold technique. Tumori 99: 76-82.

[47] Sager O, Beyzadeoglu M, Dincoglan F, Oysul K, Kahya YE, et al. (2012) Evaluation of active breathing control-moderate deep inspiration breath-hold in definitive non-small cell lung cancer radiotherapy. Neoplasma 59: 333-340.

[48] Sager O, Beyzadeoglu M, Dincoglan F, Oysul K, Kahya YE, et al. (2012) The Role of Active Breathing Control-Moderate Deep Inspiration Breath-Hold (ABC-mDIBH) Usage in nonMastectomized Left-sided Breast Cancer Radiotherapy: A Dosimetric Evaluation UHOD - Uluslararasi Hematoloji-Onkoloji Dergisi 22: 147-155.

[49] Sağer Ö, Dinçoğlan F, Gamsiz H, Demiral S, Uysal B, et al. (2012) Evaluation of the impact of integrated [18f]-fluoro-2-deoxy-D-glucose positron emission tomography/computed tomography imaging on staging and radiotherapy treatment volume definition of nonsmall cell lung cancer. Gulhane Med J 54: 220-227.

Citation: Omer Sager, Ferrat Dincoglan, Selcuk Demiral, Murat Beyzadeoglu. Evaluatıon of Target Volume Determination for Irradiatıon of Pilocytıc Astrocytomas: An Original Artıcle. ARC Journal of Cancer Science. 2020; 6(1):19-23. DOI:dx.doi.org/10.20431/2455-6009.0601003.

Copyright: (C) 2020 Authors. This is an open-access article distributed under the terms of the Creative Commons Attribution License, which permits unrestricted use, distribution, and reproduction in any medium, provided the original author and source are credited. 